\title{
Defluoridation of drinking water using coalesced and un-coalesced mica
}

\author{
Idd Ally Hussein ${ }^{1} \cdot$ Maheswara Rao Vegi $^{1}$
}

Received: 9 May 2019 / Accepted: 21 January 2020 / Published online: 28 January 2020

(c) The Author(s) 2020

\begin{abstract}
This is a sorption study that focused on the use of mica clay mineral grouped into mica untreated, activated mica at $800{ }^{\circ} \mathrm{C}$, mica impregnated separately with iron and aluminium for defluoridation of water. In this study, characterization of adsorbent was done by using XRF and XRD and quantification of fluoride by using fluoride ion selective electrode. Characterization of adsorbent showed the presence of $\mathrm{SiO}_{2}, \mathrm{CaO}, \mathrm{P}_{2} \mathrm{O}_{5}, \mathrm{Fe}_{2} \mathrm{O}_{3}$ and $\mathrm{Al}_{2} \mathrm{O}_{3}$ in the adsorbent. XRD exhibited higher composition of illite, calcite, quartz and albite. Batch experiments were conducted by using a homogeneous mixture of water having $16 \mathrm{mg} / \mathrm{L}$ of fluoride. The removal efficiencies of mica alone, activated mica at $800{ }^{\circ} \mathrm{C}$, mica impregnated with iron and mica impregnated with aluminium were found to be $76.02 \%, 90.21 \%, 94.40 \%$ and $96.88 \%$, respectively. Activated mica and coalesced mica are better adsorbents than mica alone. The optimized pHs were 7.3, 4.4, 7.5, doses of 10, 9 and $8 \mathrm{~g}$, contact time of 40, 35 and 30 min for activated mica, mica impregnated with iron and mica impregnated with aluminium, respectively. The adsorption process obeyed Freundlich model for mica impregnated with aluminium indicating monolayer mechanism, whereas activated mica and mica impregnated with iron agreed with both Freundlich and Langmuir models indicating both monolayer homogeneous and heterogeneous surface conditions. From the kinetic perspective, the fluoride adsorptive reaction followed the pseudo-second-order model. Therefore, activated and modified mica are alternative adsorbents for defluoridation of water.
\end{abstract}

Keywords Mica $\cdot$ XRF $\cdot$ XRD $\cdot$ Adsorbent $\cdot$ Defluoridation $\cdot$ Fluoride ion selective electrode

\section{Introduction}

Defluoridation of drinking water is still a tremendous challenge in different countries around the world. Fluoride is naturally present in water everywhere, air and food (Baris et al. 2009). It enters the food via drinking water. At concentration of approximately $1 \mathrm{mg} / \mathrm{L}$, fluoride in drinking water, it can provide significant protection against dental decay and aids in bone development (Kaseva 2006; Jamode et al. 2004), while at above $1.5 \mathrm{mg} / \mathrm{L}$ concentration, fluoride is dangerous to human health (Littleton 1999) as it leads to dental and skeletal fluorosis (Chibi and Haarhoff 2000), a disease that can cause mottling of the teeth, calcification of ligaments, crippling deformities of bones and many other

Maheswara Rao Vegi

vegimahesh@gmail.com

1 Department of Chemistry, College of Natural and Mathematical Sciences, The University of Dodoma, P.O. Box: 259, Dodoma, Tanzania physiological disorders that can ultimately lead to death (Renuka and Pushpanji 2013). Fluoride has also been linked with cancer, decreased cognitive ability, lowered intelligence quotient (IQ) and developmental issues in children (Kundu et al. 2015).

Fluorosis is endemic in at least 25 countries around the world. Many people are currently afflicted with the disease; even conservative estimates give data regarding the same in terms of tens of millions of people (Tokaryk 2011). There is no treatment for fluorosis, something which leaves prevention as the only means of controlling the spreading of the disease worldwide. It has been a major challenge worldwide to develop effective and inexpensive techniques for the remediation of fluoride in drinking water.

In Tanzania, people obtain water from various sources including rain, surface waters (lakes, rivers and ponds) and groundwater (boreholes, shallow well and springs) (Shorter 2011). Groundwater is the main source of water in Tanzanian rural areas especially in Hai District of Kilimanjaro Region. It is well known that groundwater contains dissolved 
gases and minerals, including fluoride salts. Some parts of the earth's crust contain minerals with high levels of fluoride ion. When groundwater is in contact with these minerals, soluble fluoride salts dissolve, thus releasing fluoride ions in water (Othman et al. 2014).

It is reported in the literature that there are high fluoride concentrations in groundwater in some parts of Tanzania which range from 17 to $46 \mathrm{mg} / \mathrm{L}$ (Olambo et al. 2016). Hai District has a moderate concentration of $8-25 \mathrm{mg} / \mathrm{L}$ of fluoride (Shorter 2011). Though it is less than the highest in Tanzania, this area has been reportedly chosen for the present study because the people living there have highly been affected with dental and skeletal fluorosis. There is also an additional advantage in conducting this research work in the selected area as there is Ngurdoto Defluoridation Research Centre (NDRC) in Arusha which is nearby and also due to the availability of raw materials in the surrounding areas. This research also intends to explore tailor-made, low-cost and domestic treatment methods which suit this region since the people of this region are very poor.

There are well-studied defluoridation methods using some of the adsorbent materials including lime and alum (Nalgonda technology), activated clay, activated alumina and bone char. These defluoridation techniques have one or more weaknesses including the need for high chemical doses, large amounts of sludge, they are not available in the Tanzania context, and they have slow and low fluoride removal capacity (Olambo et al. 2016). But some of the adsorbents tried previously are relatively inexpensive and are at the same time endowed with reasonable adsorption capacity. These include natural soil (Chidambaram et al. 2013), quick lime (Islam and Patel 2007), powdered activated charcoal (Tembhurkar and Dongre 2006), magnesite (Singano et al. 1995), brick powder (Yadav et al. 2006), carbonaceous adsorbents (Abe et al. 2004), leaves of Azadirachta indica (Tembhurkar and Dongre 2006), calcinated red clay soil (Othman et al. 2014), rice husk (Waheed et al. 2009), coconut shells activated carbon (Said and Machunda 2014), tamarind seed (Murugan and Subramanian 2006), kaolin-feldspar blend (Lugwisha and Lunyungu 2016), cynodon dactylon-based activated carbon (Alagumuthu et al. 2010), peels of Citrus documana, Citrus medica and Citrus aurantifolia fruits-based activated carbon (Chakrapani et al. 2010). Other reported methods involve electrolytic techniques and ion exchange, which are deemed to be expensive to developing countries such as Tanzania (Olambo et al. 2016).

Mica is a group of sheet silicate (phyllosilicate) minerals which include several closely related materials having nearly basal cleavage. Mica is classified according to its colour and structure. Colour classification includes purple, rosy, silver, grey (lepidolite), dark green, brown, black (biotite), yellowish-brown, green-white (phlogopite), colourless and transparent (muscovite), while structural classifications are dioctahedral and trioctahedral (Abdullah et al. 2013). Mica used in this study is black and brown mica identified by geologists, and it is more available in their respective sites.

Thus, this study focuses on the use of mica, a clay mineral, coalesced and un-coalesced which has not been tested so far to remove fluoride in water. It was carried out in the department of chemistry, The University of Dodoma, Tanzania.

\section{Materials and methods}

\section{Description of study site}

Hai District is one of the seven districts of the Kilimanjaro Region of Tanzania (Fig. 1); it is found at $3^{\circ} 10^{\prime \prime} \mathrm{S}$ and $37^{\circ}$ $10^{\prime \prime} \mathrm{E}$ and bordered to the south and west by the Arusha Region, to the west by the Siha District and to the east by the Moshi Urban District and Moshi Rural District and the Rombo District, respectively. The population is predominantly rural with the largest town being Bomang'ombe situated on the main road that runs through the centre of Hai District.

\section{Water sampling}

Water samples were collected from seven wells and one spring from eight different villages distributed into different wards at Hai District in Kilimanjaro Region of Tanzania by using high-density polyethylene (HDPE) bottles. These bottles were first washed by distilled water three times and then rinsed by the water to be sampled. The collected water was mixed well together to obtain homogeneous mixture and transported to Ngurdoto Defluoridation Research Centre (NDRC) for analysis.

\section{Adsorbent sampling and preparation}

Mica was collected from five different sites at mountains found in Namugenzi village at Mahenge/Ulanga District in Morogoro Region by crushing stones embedded with mica to obtain pieces; then, these were transported to Geological Survey of Tanzania (GST) laboratory, where they were ground by using grinder mill machines and sieved into small-sized particles by sieve machines having mesh sizes of $<75,75,150,425,710 \mathrm{~mm}$. Then, powdered mica was packed into poly bags and sealed tightly for further analysis.

\section{Categorization of mica}

Mica was categorized into mica untreated $(\mathrm{M})$, thermally activated mica at $800{ }^{\circ} \mathrm{C}$ (MAA) for $2 \mathrm{~h}$ using muffle furnace (Nabertherm, Germany), mica mixed with iron (MI) $\left(\mathrm{FeCl}_{3}\right.$, 


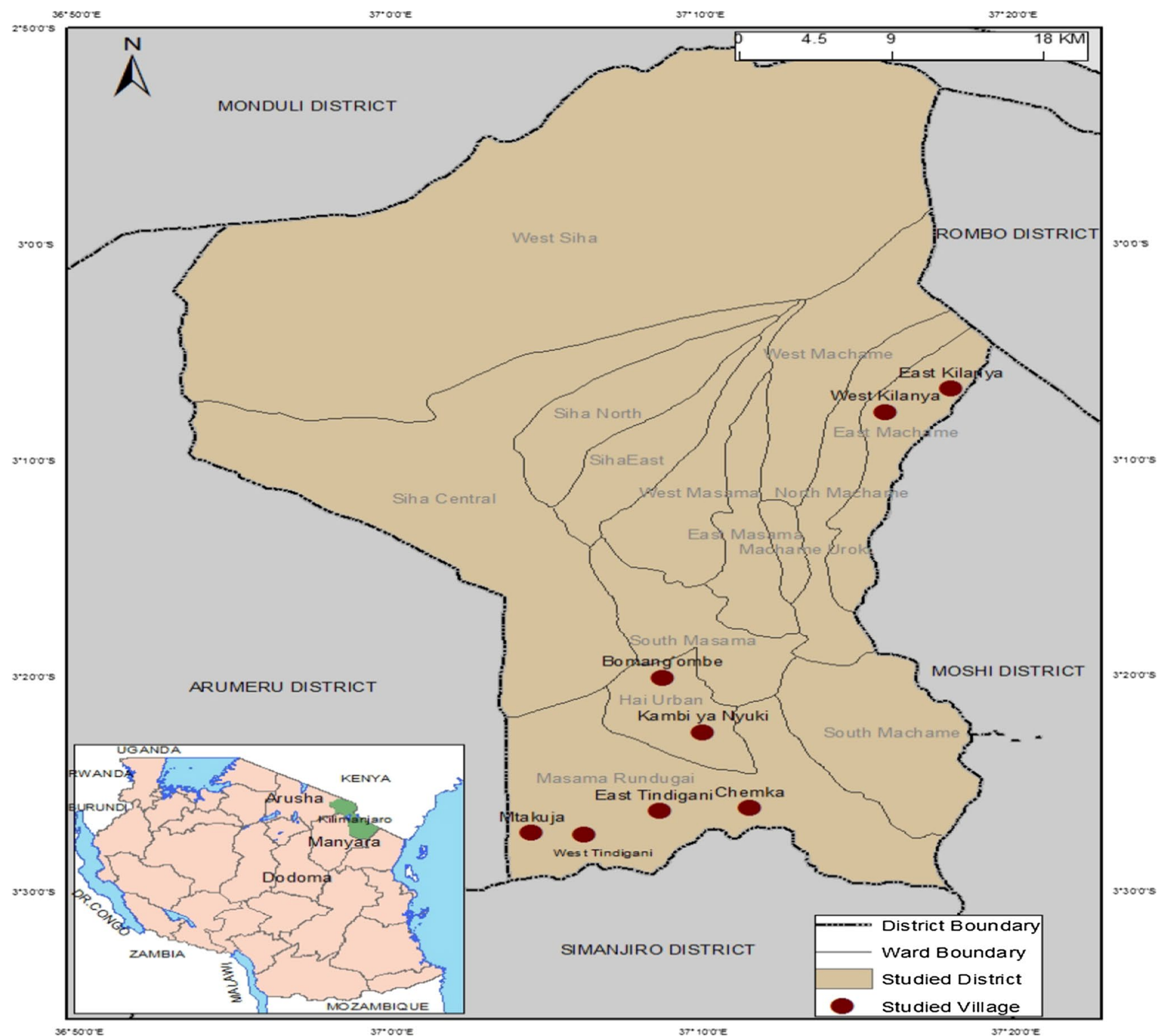

Fig. 1 Map of Hai District and its borders extracted from map of Tanzania

assay $99.5 \%$, Kemira chemicals, UK) in different ratios (4:1, 6:1 and 8.9:0.1 g) and mica mixed with aluminium (MA) $\left(\mathrm{Al}_{2}\left(\mathrm{SO}_{4}\right)_{3}\right.$, assay $99.6 \%$, Kemira chemicals, UK) in different ratios $(4: 1,6: 1$ and 8.9:0.1 g).

\section{Characterization of mica}

X-ray fluorescence (XRF) analysis for the composition of elements present in adsorbents M, MI and MA was carried out by using XRF spectrometer (MINI PAL 4). XRF analysis was not performed for MAA, because of denaturation of mica during activation process. The samples were thoroughly ground into a fine powder, and then, $4.9 \mathrm{~g}$ of $\mathrm{M}$ was mixed with $0.1 \mathrm{~g}$ of iron and aluminium separately to make $5 \mathrm{~g}$ for the MI and MA. Un-coalesced M (5 g) was placed in a small plastic cup covered with plastic at the bottom. Finally, this cup was introduced into XRF spectrometer as a target for the analysis and determination of elemental and percentage composition of the different adsorbents. The results are summarized in Table 1.

$\mathrm{X}$-ray diffractograms were obtained from XRD analysis (XRD, D2-PHASER, Bruker) for the mineralogical composition of mica. In a typical procedure, mica samples ground into powder and sized small particles of $75 \mathrm{~mm}$ were packed into an aluminium holder, which was then placed in goniometer and bombarded with X-rays generated from cobalt tubes. The XRD was operated at $32 \mathrm{kV}$, $33 \mathrm{~mA}$ and $2 \theta$ ranges from $10^{\circ}$ to $70^{\circ}$. The results are displayed on the screen that is the XRD diffractogram of mica is shown in Fig. 2. 
Table 1 Elemental composition of mica before and after coalescing obtained from XRF analysis

\begin{tabular}{|c|c|c|c|c|}
\hline \multicolumn{2}{|c|}{ Before coalescing } & \multicolumn{3}{|c|}{ After coalescing } \\
\hline \multicolumn{2}{|c|}{ Adsorbent type (\%) } & \multicolumn{3}{|c|}{ Adsorbent type (\%) } \\
\hline Composition & M & Composition & MI & MA \\
\hline $\mathrm{SiO}_{2}$ & 38.80 & $\mathrm{SiO}_{2}$ & 23.5 & 19.9 \\
\hline $\mathrm{Fe}_{2} \mathrm{O}_{3}$ & 20.40 & $\mathrm{Fe}_{2} \mathrm{O}_{3}$ & 53.47 & 49.65 \\
\hline $\mathrm{Al}_{2} \mathrm{O}_{3}$ & 14.50 & $\mathrm{Al}_{2} \mathrm{O}_{3}$ & 6.7 & 7.6 \\
\hline $\mathrm{K}_{2} \mathrm{O}$ & 8.45 & $\mathrm{~K}_{2} \mathrm{O}$ & 11.0 & 11.1 \\
\hline $\mathrm{MgO}$ & 6.84 & $\mathrm{P}_{2} \mathrm{O}_{5}$ & 0.57 & 0.66 \\
\hline $\mathrm{TiO}_{2}$ & 3.01 & $\mathrm{TiO}_{2}$ & 4.91 & 5.00 \\
\hline $\mathrm{Na}_{2} \mathrm{O}$ & 0.62 & $\mathrm{CuO}$ & 0.15 & 0.12 \\
\hline $\mathrm{CaO}$ & 0.405 & $\mathrm{CaO}$ & ND & ND \\
\hline $\mathrm{MnO}$ & 0.32 & $\mathrm{MnO}$ & 0.69 & 0.62 \\
\hline \multirow[t]{8}{*}{$\mathrm{Cl}$} & 0.15 & $\mathrm{Cl}$ & ND & ND \\
\hline & & $\mathrm{SrO}$ & 0.057 & 0.061 \\
\hline & & $\mathrm{V}_{2} \mathrm{O}_{5}$ & 0.10 & 0.14 \\
\hline & & $\mathrm{ZnO}$ & 0.17 & 0.19 \\
\hline & & $\mathrm{ZrO}_{2}$ & ND & ND \\
\hline & & $\mathrm{NiO}$ & 0.03 & 0.14 \\
\hline & & $\mathrm{BaO}$ & ND & ND \\
\hline & & $\mathrm{SO}_{3}$ & ND & ND \\
\hline
\end{tabular}

\section{Preparation of TISAB II}

The total ionic strength adjustment buffer (TISAB II) was prepare by taking $57 \mathrm{~mL}$ of glacial acetic acid (assay $99.8 \%$, Sigma-Aldrich, Germany), $58 \mathrm{~g}$ of sodium chloride (assay 99.5\%, Sigma-Aldrich, Germany), $4 \mathrm{~g}$ of cyclohexane diamine tetraacetic acid (assay 99.8\%, Kemira chemicals, UK) and $0.5 \mathrm{~g}$ trisodium citrate (assay $99.8 \%$, Kemira chemicals, UK) in $500 \mathrm{~mL}$ distilled water and allowed to dissolve; then, the $\mathrm{pH}$ was adjusted to 5.3 by using well-prepared $1 \mathrm{M}$ $\mathrm{NaOH}$ (assay 99.6\%, Sigma-Aldrich, Germany) and $1 \mathrm{M}$ $\mathrm{HCl}$ (assay 99.8\%, Sigma-Aldrich, Germany), transferred into one litre volumetric flask filled with distilled water up to the mark.

\section{Calibration of the instrument}

Calibration of the fluoride ion selective electrode was done by preparing five standards of fluoride solution with the concentration of $5,10,15,20$ and $25 \mathrm{mg} / \mathrm{L}$ by the serial dilution of fluoride standard (assay 99.5\%, Kemira chemicals, UK) with distilled water; then, calibration graph of voltage versus concentration was plotted from the data obtained

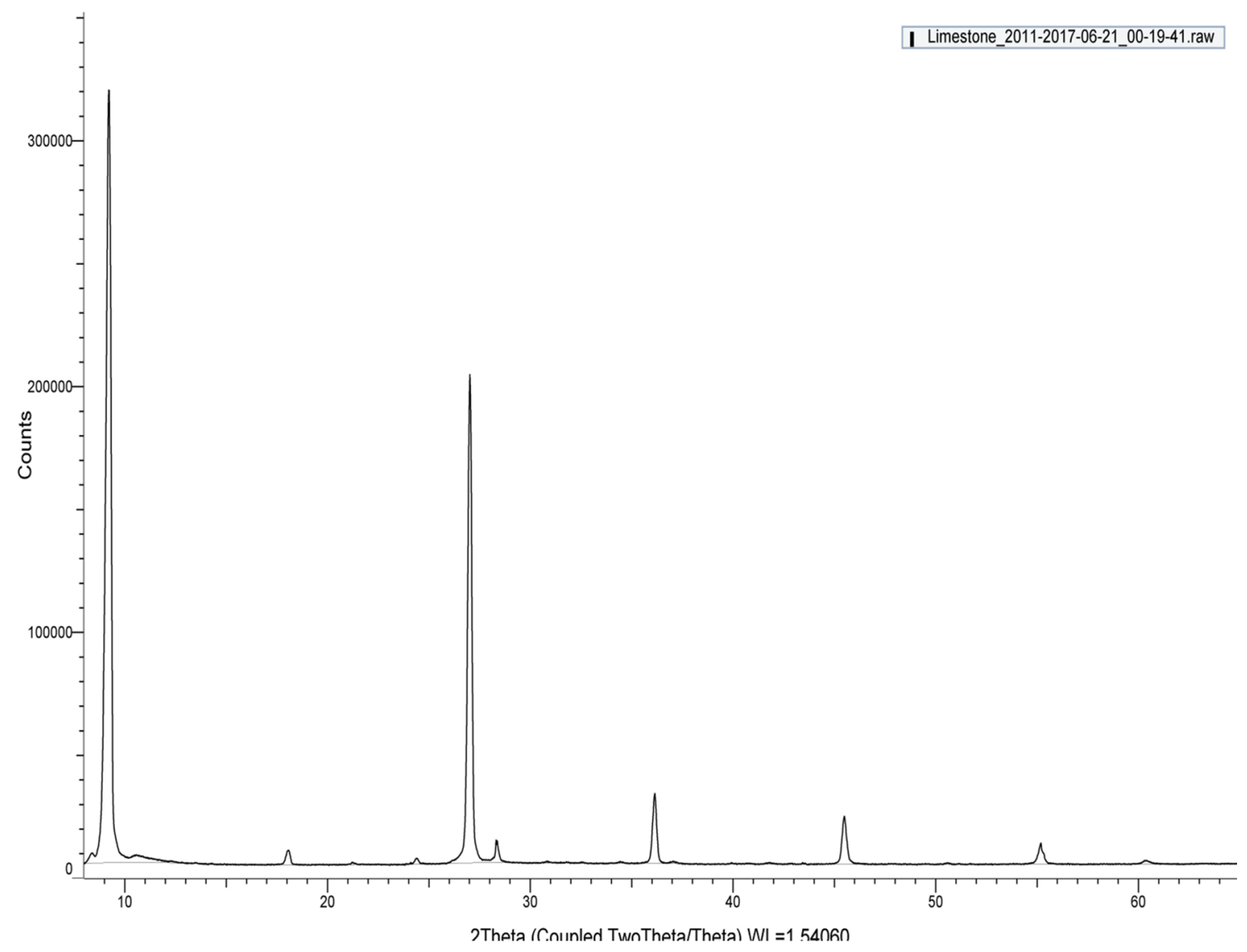

Fig. 2 X-ray diffractogram of mica 
from the potentiometer connected with fluoride ion selective electrode.

\section{Water analysis for fluoride}

Concentration of fluoride ions present in water sample was measured by ion selective electrode (Orion 4 star, India) connected to potentiometer. Before measuring concentration of fluoride in water sample, calibration was done each time in order to obtain required slope and compare it with theoretical values. Equal volumes of $5 \mathrm{~mL}$ of water sample and TISAB II solution were mixed and were placed into 50-mL plastic beaker, and the mixture was stirred by speed of $360 \mathrm{rpm}$ for $1 \mathrm{~min}$ by using a magnetic stirrer. In all the experiments, the same amount of sample was used and the experiments were done in triplicate (Agarwal et al. 2003). The concentrations were determined by interpolation using calibration curves from the measured voltages.

\section{Preliminary test}

Preliminary test was carried in the beginning of the experiment to check the adsorption performance of all adsorbents. $50 \mathrm{~mL}$ of the solution having initial fluoride concentration of $16 \mathrm{mg} / \mathrm{L}$ from the source was transferred into each of the three small plastic bottles; $5 \mathrm{~g}$ of M, MAA and MI (4:1 g) adsorbent was added independently, and then placed on magnetic stirrer and rotated at a speed of $360 \mathrm{rpm}$. A filtrate of $5 \mathrm{~mL}$ was drawn at different intervals of time $(0.5,1,2,3$, $4,5,8,12$ and $24 \mathrm{~h}$ ) and mixed with $5 \mathrm{~mL}$ of TISAB II, and then, fluoride concentration was determined.

After preliminary test, impregnation test was conducted to check the best ratio which gives maximum adsorption of fluoride. Mica coalesced with iron in the ratio of $4: 1 \mathrm{~g}, 6: 1 \mathrm{~g}$ and 8.9:0.1 g was separately placed into small plastic bottles containing $50 \mathrm{~mL}$ of water with initial fluoride concentration of $16 \mathrm{mg} / \mathrm{L}$, agitated at $360 \mathrm{rpm}$. Filtrates were withdrawn at $5,10,15,20,25,30,40,50,60,70,80,90,100,110$ and 120 min intervals. Time intervals were selected based on preliminary test result which showed best performance of adsorbents below 2 h. Finally, fluoride concentrations were determined. The same procedure was repeated for mica mixed with aluminium.

\section{Batch adsorption experiments}

All batch experiments were conducted by using $50 \mathrm{~mL}$ of aqueous solution of sodium fluoride (assay 99.4\%, SigmaAldrich, Germany) with a concentration of $16 \mathrm{mg} / \mathrm{L}$ to which a weighed amount of MAA, MI and MA was separately added into three small plastic bottles. The mixture was shaken by using magnetic stirrer under room temperature with a speed of $360 \mathrm{rpm}$. A sample was periodically taken out from each bottle and filtered by using Whatman filter paper no. 01. Fluoride ion concentrations in water were determined using fluoride ion selective electrode.

\section{Optimization of different parameters}

Optimization of different parameters was done by studying one parameter at a time by keeping the remaining parameters constant. The effects of various parameters on percentage of adsorption were recorded by varying contact time, $t(5,10$, $15,20,25,30,40,50,60,70,80,90,100,110$ and $120 \mathrm{~min})$, initial concentration $C_{0}(8,12,16,20$ and $24 \mathrm{mg} / \mathrm{L})$, $\mathrm{pH}$ of solution $(1,2,3,4,5,6,7,8,9,10$ and 11) and adsorbent dosage, $\mathrm{m}(1,2,3,4,6,7,8,10,13,15,18$ and $21 \mathrm{~g})$, particle size ranges of $<75,75,150,250,425,710 \mathrm{~mm}$ and temperature $100,200,300,400,500,600,700,800,900{ }^{\circ} \mathrm{C}$. In all the cases, the volume of water taken was $50 \mathrm{~mL}$. The percentage adsorptions of fluoride at any instant of time and defluoridation capacity were determined by Eqs. (1) and (2) (Vijaya and Krishnaiah 2009; Solangi et al. 2009):

$\%$ Adsorption $=\frac{\left(C_{0}-C_{t}\right)}{C_{0}} \times 100$

Deflouridation capacities, $q_{e}\left(\frac{m g}{g} \mathrm{~F}^{-}\right)=\frac{\left(C_{o}-C_{t}\right)}{m} \times v$

where $C_{0}=$ initial $\mathrm{F}^{-}$concentration, $C_{t}=$ residual fluoride concentration at time $t, m=$ mass of adsorbent, and $v=$ volume of the solution used in the batch.

\section{Generation of adsorption isotherms}

Adsorption isotherms were generated and analysed for MAA, MI and MA with the prepared concentrations of 5, $10,15,20$ and $25 \mathrm{mg} / \mathrm{L}$ sodium fluoride, mixed with the optimized doses of 10,9 and $8 \mathrm{~g}$, respectively. The adsorbent liquid mixture was agitated for the optimized contact time of each adsorbent to ensure equilibrium. A residual fluoride in solution was determined. All the values necessary to plot the isotherm were calculated from these.

\section{Adsorption kinetics for fluoride}

Adsorption kinetics was studied for initial fluoride concentration of 16,20 and $24 \mathrm{mg} / \mathrm{L}$ with the corresponding adsorbent doses of 8,10 and $14 \mathrm{~g}$, respectively. The residual fluoride concentrations data obtained in kinetics were fitted in pseudo-first-order and second-order rate equations to get best-fitting kinetic model. 


\section{Regeneration procedure}

Regeneration of the already used adsorbents was done by first washing the adsorbent with $0.1 \mathrm{M} \mathrm{Na}_{2} \mathrm{CO}_{3}$ followed by $1 \% \mathrm{HCl}$, dried by drier, ground by mortar and pestle and to get uniform-sized particle. Regeneration removes the previously sorbed $\mathrm{F}^{-}$from the surface. The addition of $\mathrm{Na}_{2} \mathrm{CO}_{3}$ releases $\mathrm{F}^{-}$from the clay surface, and the use of $1 \% \mathrm{HCl}$ reactivates the surface for $\mathrm{F}^{-}$adsorption. The optimized doses of each adsorbent were placed into small plastic bottle, and then, water having initial concentration from site was added and agitated for the optimized contact time, then left to cool and filtered. Then, the concentration of fluoride was determined. The conditions maintained at initial fluoride ion concentration in water were $16 \mathrm{mg} / \mathrm{L}$, $\mathrm{pH}$ is 7.5, 4.4 and 7.3 for MAA, MI and MA, respectively, adsorbent dose was 10, 9 and $8 \mathrm{~g}$, respectively, for MAA, $\mathrm{MI}$ and MA, and the volume of water was $50 \mathrm{~mL}$.

\section{Results and discussion}

\section{Characterization of adsorbents}

The pattern of adsorption of fluoride by the adsorbent mica is attributed to the presence of silicon, iron and aluminium in the form of oxide which is the good adsorbent. From Table 1, it is observed that before impregnation, mica had higher percentages of $\mathrm{SiO}_{2}$ followed by $\mathrm{Fe}_{2} \mathrm{O}_{3}, \mathrm{Al}_{2} \mathrm{O}_{3}$ and $\mathrm{K}_{2} \mathrm{O}$. After impregnation of mica with iron and aluminium, the order of percentage composition changed to $\mathrm{Fe}_{2} \mathrm{O}_{3}$ followed by $\mathrm{SiO}_{2}, \mathrm{Al}_{2} \mathrm{O}_{3}$ and $\mathrm{K}_{2} \mathrm{O}$. This change is due to the structural changes on addition of component which is already present, and it is expected to have different adsorption capacities. Fluoride was not detected in XRF spectrometer (MINI PAL 4) because its atomic weight is below 11 (Olambo et al. 2016).

It is observed from the diffractogram of mica (Fig. 2) that the peaks are sharp and there are no any scattered peaks, indicating that mica is highly crystalline without any defects in the crystal. The high intense peak (a) at $2 \theta=27^{\circ}$ indicates illite $\left(\left(\mathrm{K}, \mathrm{H}_{3} \mathrm{O}\right)(\mathrm{Al}, \mathrm{Mg}, \mathrm{Fe})_{2}(\mathrm{SiAl})_{4} \mathrm{O}_{10}\right.$ $\left.\left[(\mathrm{OH})_{2}\left(\mathrm{H}_{2} \mathrm{O}\right)\right]\right)$ with the highest percentage composition of $61.72 \%$. The peak (d) at $2 \theta=36^{\circ}$ represents quartz with $28.96 \%$ of $\left(\mathrm{SiO}_{2}\right)$. Peaks (f), (g), (e) (b) and (c) at $2 \theta=45^{\circ}$, $55^{\circ}, 18^{\circ}, 24^{\circ}$ and $61^{\circ}$ indicate the presence of $6.03 \%$ of albite $\left(\mathrm{NaAlSi}_{3} \mathrm{O}_{8}\right), 0.82 \%$ pyrite $(\mathrm{FeS}), 0.81 \%$ of calcite, $0.53 \%$ of dolomite $\left(\mathrm{CaMg}\left(\mathrm{CO}_{3}\right)_{2}\right)$ and $0.33 \%$ of chlorite $\left(\mathrm{ClO}_{2}\right)$, respectively, in the adsorbent. The clay minerals with higher percentage of iron, aluminium, calcium and silicon in its composition are good adsorbents.

\section{Calibration of ion selective electrode}

The plot of potential in millivolts versus the logarithms of concentration of fluoride ion resulted in a straight line with negative slope of $57.1200 \mathrm{mV}$ at $25^{\circ} \mathrm{C}$, which is within the range of -55 to $-60 \mathrm{mV}$ according to the theory (Getachew et al. 2015). The linearity of the graph is indicated by the correlation coefficient of -0.9999 . The accuracy of the analytical data was ensured by triplicate measurements and checked by standard deviations. These values are in good range for the measured concentration of fluoride.

\section{Preliminary test}

Activated mica showed up to $82.08 \%$ of adsorption in less than $2 \mathrm{~h}$, because heating increases the number of pores and active sites present on the surface of the adsorbent. This is high compared to adsorption by untreated mica with highest percentage of adsorption of $76.02 \%$. Mica impregnated with iron gave the best percentage of adsorption of $92.82 \%$ compared to the other two adsorbents. This was because added iron modified its composition. Therefore, further experiments were conducted with activated mica and mica coalesced with iron and aluminium as adsorbents.

Mica impregnated with iron and aluminium separately in different ratios (4:1, 6:1 and 8.9:0.1) showed good adsorption of fluoride onto its surface within $35 \mathrm{~min}$. The highest percentages of adsorption for mica impregnated with iron were $92.48,94.35$ and 95.63 for the ratios 4:1, 6:1 and 8.9:0.1, respectively. Similarly, mica impregnated with aluminium showed the percentage adsorption of $93.33 \%$ for $4: 1$, $95.21 \%$ for $6: 1$ and $96.75 \%$ for $8.9: 0.1$. In both cases, the ratio 8.9:0.1 showed highest percentage of adsorption and was chosen for other adsorption experiments. The reason for high efficiency of this ratio is increased in the surface area and positive charges on the adsorbent. This result is similar to that reported by Janardhana and his co-workers for activated charcoal impregnated with metal ions (Janardhana et al. 2006).

\section{Optimization of factors affecting fluoride removal from water}

The parameters such as contact time, initial fluoride concentration, $\mathrm{pH}$, adsorbent dosage, temperature and particle size which affect the removal of fluoride ions were optimized by varying each of them at a time by keeping the remaining parameters constant. The results are presented below.

\section{Effect of contact time}

Batch adsorption procedure was used, and residual fluoride concentrations were measured for different contact times 
of $5,10,15,20,25,30,40,50,60,70,80,90,100,110$ and $120 \mathrm{~min}$ in order to investigate the effect of contact time on percentage adsorption. Initial fluoride ion concentration in water is $16 \mathrm{mg} / \mathrm{L}$, volume of water taken is $50 \mathrm{~mL}$, adsorbent dosage is $9 \mathrm{~g} / 50 \mathrm{~mL}$, speed of stirring is $360 \mathrm{rpm}$, amount of filtrate withdrawn was $5 \mathrm{~mL}$, and fluoride buffer taken was $5 \mathrm{~mL}$. The effect of contact time on fluoride adsorption efficiency is shown in Fig. 3a. It seems that all of the three adsorbents had good capacity for adsorption of fluoride. All of the three adsorbents exhibited similar trend of increase in the percentage adsorption with contact time up to 30-40 min and then remained constant, but there was difference in their percentage adsorption.
Mica mixed with aluminium (MA) showed outstanding adsorption of $96.81 \%$ within a shortest time of $30 \mathrm{~min}$ and remained constant up to $2 \mathrm{~h}$ after attaining equilibrium. This means that all of the active sites for binding fluoride ions become occupied with in a shortest time. Next to this, mica mixed with iron (MI) also had shown $95.63 \%$ of the adsorption within 35 min. Lastly, activated mica (MAA) showed $84.98 \%$ of adsorption within $40 \mathrm{~min}$. This means that activation created cations opened pores for the fluoride anions to bind on it. Similar trend is found in the literature on activated carbon adsorbents derived from the peels of selected citrus fruits (Chakrapani et al. 2010; Parmar et al. 2006).
Fig. 3 Percentage adsorption of MAA, MI and MA versus a contact time, $\mathbf{b}$ initial fluoride concentration, $\mathbf{c} \mathrm{pH}, \mathbf{d}$ adsorbent dosage, e particle size and f temperature
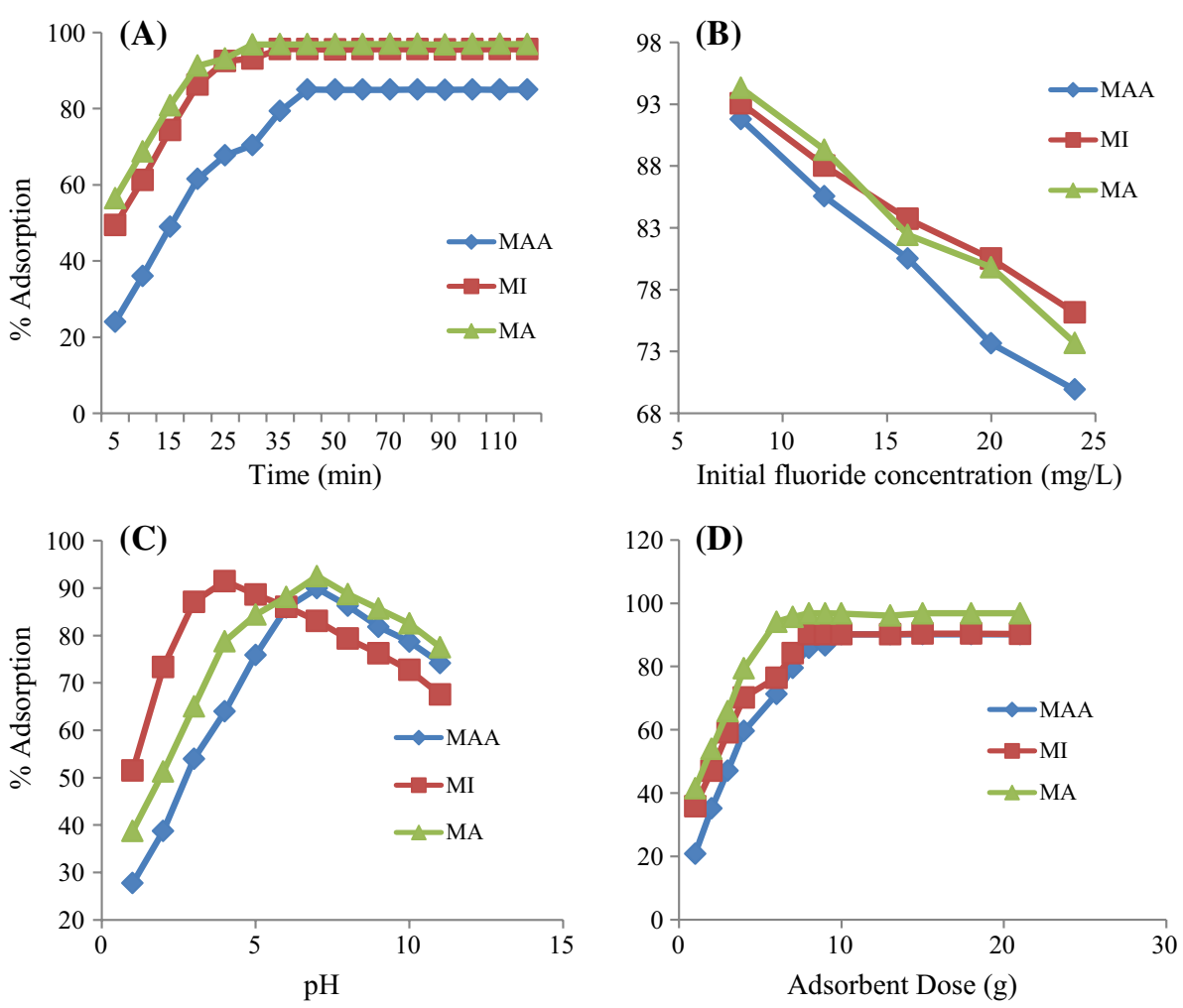

(E)

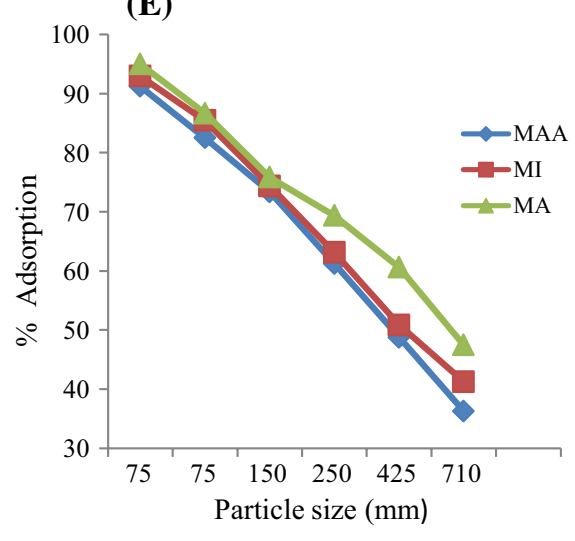

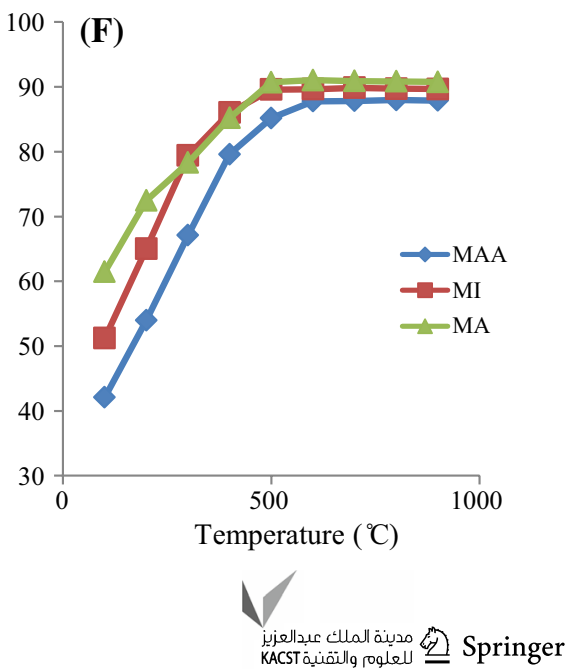




\section{Effect of initial fluoride concentration}

The effect of initial fluoride concentrations on the adsorption of fluoride was studied by varying the initial fluoride concentrations of $8,12,16,20$ and $24 \mathrm{mg} / \mathrm{L}$ and keeping the other parameters constant at 120 min of contact time, $9 \mathrm{~g} / 50 \mathrm{~mL}$ of adsorbent dose, $50 \mathrm{~mL}$ of water and $360 \mathrm{rpm}$ of speed of stirring. The percentage adsorption of all the adsorbents at different initial fluoride concentrations is shown in Fig. 3b. It is observed that maximum adsorption occurred at lower fluoride concentration for all the adsorbents. This is due to the intensively utilization of all active sites at the surface of adsorbent. The percentage of adsorption decreased with the increase in the initial concentration of fluoride. This is because all active sites had already been occupied and incoming fluoride ion from water was repelled by repulsive forces (Getachew et al. 2015). Therefore, it is very important to determine initial fluoride concentration at the beginning of any adsorption experiment because parameters like $\mathrm{pH}$, contact time and doses depend much on initial concentration of fluoride in water.

\section{Effect of $\mathrm{pH}$}

One of the important parameters for adsorption of fluoride is $\mathrm{pH}$ which can be acidic, neutral and basic. In the case of mica impregnated with iron, maximum adsorption of fluoride occurred under slightly acidic condition with the percentage of adsorption of $89.94 \%$ (Fig. 3c). Under this condition, the oxides of iron, aluminium and silicon provide more positive charge for the fluoride to bind on it. When $\mathrm{pH}$ increased to more basic condition, the percentage of adsorption decreased slowly because no more cations were produced by the oxides of iron, aluminium and silicon. For MAA and MA, maximum percentage of adsorption was $91.46 \%$ and $92.50 \%$, respectively, at nearly neutral condition. This is because of the presence of charges on the adsorbents even at neutral condition and due to amphoteric nature of aluminium (Coetzee et al. 2003). The optimized pH values for MI, MAA and MA are 4.4, 7.5 and 7.3, respectively.

\section{Effect of adsorbent dosage}

Mica impregnated with aluminium (MA) showed an excellent percentage of adsorption of $96.88 \%$ with a small dose of $8 \mathrm{~g}$ of adsorbent (Fig. 3d). This is due to the presence of aluminium naturally in mica which is a good adsorbent. In addition to this, impregnation leads to further increase in the aluminium in the adsorbent, and consequently, its number of active sites for the adsorption of fluoride ions also increased. Similarly, mica mixed with iron (MI) had $94.40 \%$ of fluoride adsorption with a dose of $9 \mathrm{~g}$, but the efficiency of MI is less compared to MA. Lastly, activated mica also showed good percentage of adsorption of $90.21 \%$ with a dose of $10 \mathrm{~g}$. Even though maximum percentage adsorptions differ for MA, MI and MAA, all are very good in removing fluoride with percentage adsorptions more than $90 \%$. The maximum percentages adsorptions were obtained at dosages of 8,9 and $10 \mathrm{~g}$ for the adsorbents MA, MI and MAA, respectively. Therefore, an adsorbent dosage of 8,9 and $10 \mathrm{~g}$, respectively, for MA, MI and MAA was selected as optimal adsorbent dose for real sample treatment (Tembhurkar and Dongre 2006).

\section{Effect of particle size}

To investigate the effect of particle sizes of the adsorbents (MAA, MI and MA), different ranges of particle sizes, i.e., $<75,75,150,250,425,710 \mathrm{~mm}$, were used in the batch adsorption experiments by keeping the remaining parameters at their optimized values. All the three adsorbents showed the same general trend of decreasing percentage adsorption with the increase in the particle size. The maximum percentage of adsorption was observed at adsorbent particle size of $<75 \mathrm{~mm}$ with $91.19,92.92$ and $94.98 \%$, respectively, for MAA, MI and MA (Fig. 3e). This implies that smallest size particles have more surface area and more number of active sites for the fluoride ions to bind on them (Said and Machunda 2014; Alagumuthu et al. 2010). Therefore, a smallest particle size of $<75 \mathrm{~mm}$ was set as optimized particle size for the removal of fluoride. After comparing the maximum percentage of adsorption, MA was found to be better than MI which in turn was found to be better than MAA. This indicates that impregnation improved the adsorbent characteristics of mica.

\section{Effect of temperature}

Temperature is one of the important parameters responsible for the adsorption of fluoride on its surfaces of the adsorbent. It can be observed from Fig. $3 f$ that as the temperature increases from 100 to $800{ }^{\circ} \mathrm{C}$, adsorption increases sharply at the beginning up to $600{ }^{\circ} \mathrm{C}$, and then, it gradually increases. In the case of MAA, the maximum percentage of adsorption (87.96\%) was observed at $800{ }^{\circ} \mathrm{C}$, whereas with the case of MI and MA, it was observed at $700{ }^{\circ} \mathrm{C}$ and $600{ }^{\circ} \mathrm{C}$ with the values 89.85 and $91.02 \%$, respectively. This is because of the conversion of aluminium oxide into $\gamma-\mathrm{Al}_{2} \mathrm{O}_{3}$ and iron to magnetite at the temperature above $600{ }^{\circ} \mathrm{C}$ which leads to increase in the maximum number of pores for the binding of fluoride (Hassen 2007). Therefore, the temperature above $600{ }^{\circ} \mathrm{C}$ is suitable for mica and coalesced mica to adsorb more fluoride. 


\section{Application to real water samples}

The efficacy of MAA, MI and MA as adsorbents for removing fluoride was tested on real water samples under optimized conditions. The average concentration of fluoride in all water samples collected from eight water sources at Hai District was observed to be $16 \mathrm{mg} / \mathrm{L}$ which is above permitted level by WHO and Tanzania Bureau of Standards (TBS). One of the water samples with concentration of $16 \mathrm{mg} / \mathrm{L}$ was separately treated with the adsorbents developed in this study. Concentration of fluoride was reduced to $2.5 \mathrm{mg} / \mathrm{L}$ after treating it with activated mica which, however, is still above the safety level, but MI and MA reduced fluoride concentration to 1.3 and 0.9 , respectively, after treatment. These concentrations are less than the permissible limits.

\section{Adsorption isotherms}

The process of adsorption is usually studied through graphs known as adsorption isotherms. It is the graph between the amounts of adsorbate adsorbed on the surface of adsorbent and pressure at constant temperature. Adsorption isotherms were generated by using MAA, MI and MA with the prepared concentrations of $5,10,15,20$ and $25 \mathrm{mg} / \mathrm{L}$ for the sodium fluoride, mixed with the optimized doses of 10,9 and $8 \mathrm{~g}$, respectively. The adsorbent liquid mixture was agitated for the optimized contact time of each adsorbent to allow or ensure equilibrium. A residual fluoride in solution was determined. All the values necessary to plot the isotherm were calculated from these determinations.

Langmuir isotherm is the model developed to explain the estimation of maximum adsorption capacity corresponding to complete monolayer coverage. The linear Langmuir equation is given in Eq. (3).

$\frac{1}{q_{e}}=\frac{1}{q_{m}}+\frac{1}{k_{a} q_{m} C_{e}}$

where $C_{e}$ is the equilibrium concentration $(\mathrm{mg} / \mathrm{L}), q_{e}$ is the amount of fluoride ion adsorbed (mg/g), $q_{m}$ is $q_{e}$ for a complete monolayer $(\mathrm{mg} / \mathrm{g})$, and $K_{a}$ is adsorption equilibrium constant (Ghorai and Pant 2004).

The plot of reciprocal of specific sorption $\left(1 / q_{e}\right)$ against the reciprocal of the equilibrium concentration $\left(1 / C_{e}\right)$ for $\mathrm{F}^{-}$ions was shown for MAA and MI (Fig. $4 \mathrm{a}$ and $\mathrm{b}$ ). The essential characteristics of Langmuir isotherm can be expressed in terms of a dimensionless constant called separation factor or equilibrium parameter $R_{L}$ which is defined by Eq. (4).

$R_{L}=\frac{1}{1+b C_{0}}$
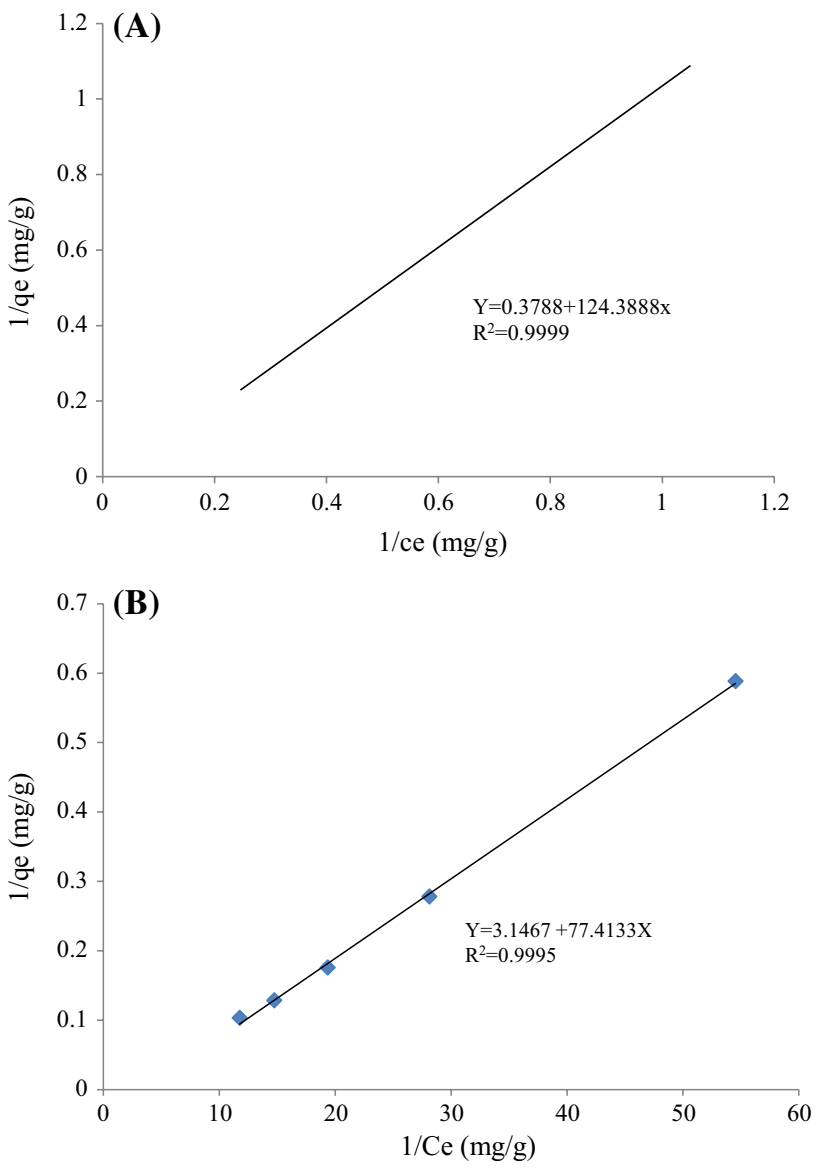

Fig. 4 Langmuir isotherms for the removal of fluoride using a activated mica (MAA) and b mica impregnated with iron (MI)

where $C_{0}$ is the initial concentration in $\mathrm{mg} / \mathrm{L}$ and $b$ is the Langmuir constant $(\mathrm{L} / \mathrm{mg})$. The parameter, $R_{L}$, indicates the shape of the isotherm such that, if $R_{L}>1$ is unfavourable, if $R_{L}=1$ is linear, if $R_{L}=0<R_{L}<1$ is favourable, if $R_{L}=0$ is irreversible (Getachew et al. 2015).

The $R_{L}$ value for MAA, MI and MA was $0.9850,0.8311$ and 0.9539 , respectively. Since these values are between zero and one, it can be concluded that the adsorption of fluoride on the surface of adsorbent under the experimental conditions is favourable.

Freundlich isotherm model assumes unlimited sorption sites which correlate with better heterogeneous surface of the adsorbent media. The linearized form of Freundlich equation represented in Eq. (5) (Said and Machunda 2014; Lv et al. 2006).

$\log q_{e}=\log k_{f}+\frac{1}{n} \log C_{e}$

where $q_{e}$ is the amount of adsorbate adsorbed per unit weight of adsorbent, in $\mathrm{mg} / \mathrm{g}, C_{e}$ is the equilibrium adsorbate concentration in solution $(\mathrm{mg} / \mathrm{L})$, and $k_{f}$ and $1 / n$ are the Freundlich constants. 
From the experimental data, the Freundlich parameters along with correlation coefficients were obtained by plotting $\log \left(q_{e}\right)$ versus $\log \left(C_{e}\right)$ (Fig. 5a and b for MAA and MI). The results indicate that there is linear relationship between the amounts (mg) of fluoride ions adsorbed per unit mass (g) of the adsorbent against the equilibrium concentration of fluoride ions in the solution $(\mathrm{mg} / \mathrm{L})$. The values of correlation coefficient obtained from these models were used to know whether the adsorption process best fit to Langmuir or Freundlich model. The adsorption process obeyed Freundlich model for MA indicating monolayer mechanism, whereas MAA and MI agreed with both models indicating both monolayer homogeneous and heterogeneous surface conditions (Shan et al. 2009).

\section{Adsorption kinetics}

The kinetic data were obtained from the sorption experiment and fitted into pseudo-first order and pseudo-second order to show the mechanisms of adsorption and potential rate controlling steps. The kinetics of the adsorption of fluoride was conducted for initial fluoride concentrations of
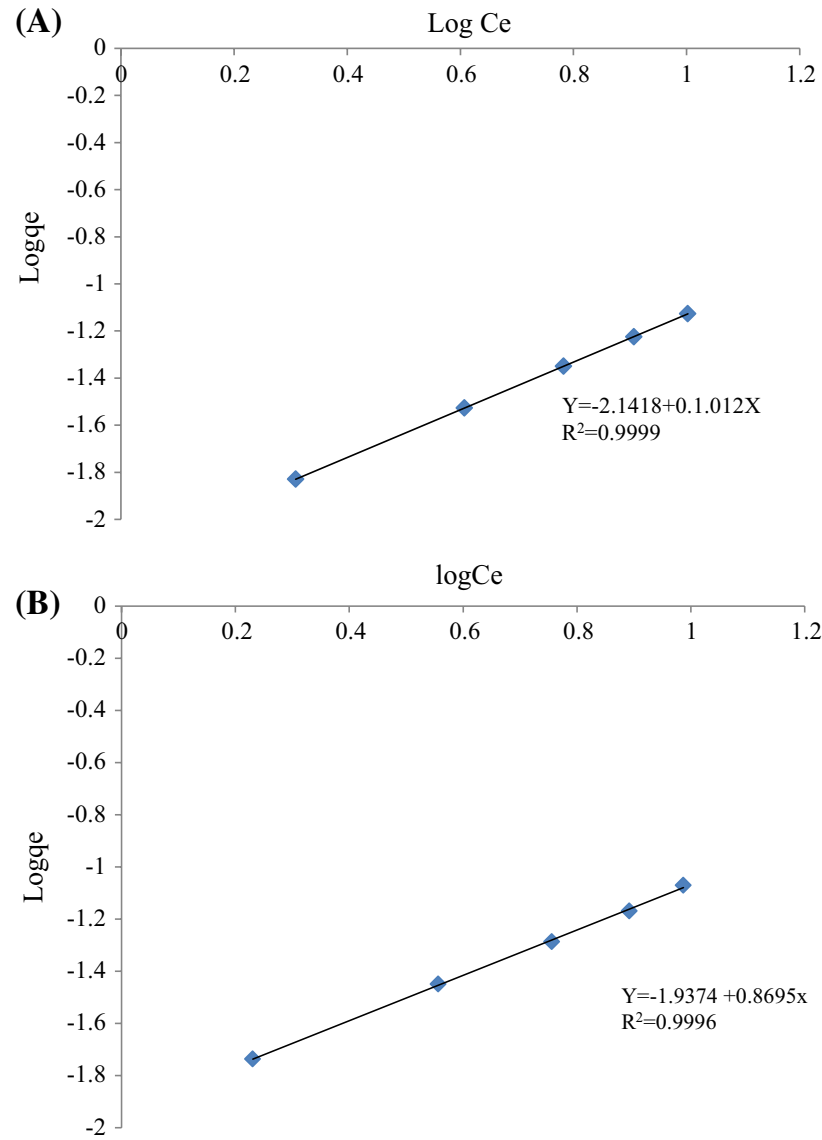

Fig. 5 Freundlich isotherm for the removal of fluoride using a activated mica (MAA) and $\mathbf{b}$ mica impregnated with iron (MI)
16, 20 and $24 \mathrm{mg} / \mathrm{L}$ prepared by using sodium fluoride and matched with the corresponding adsorbent dose of 8, 10 and $12 \mathrm{~g}$, respectively. Kinetic data analysis of fluoride sorption was studied with pseudo-first-order reaction rate model and pseudo-second-order reaction rate model to describe the kinetic process. The result showed that the experimental data fit better with the pseudo-second-order model.

Linearized form of rate equations for pseudo-first-order and pseudo-second-order rate model is given in Eqs. (6) and (7) (Hussein and Rao 2017; Baris et al. 2009).

$\log \left(q_{e}-q_{t}\right)=\log q_{e}-k_{1} t$

$\frac{t}{q_{t}}=\frac{1}{k_{2} q_{e}^{2}}+\frac{t}{q_{e}}$

where $q_{e}$ and $q_{t}$ are the amounts of fluoride adsorbed $(\mathrm{mg} / \mathrm{g})$ at equilibrium and at any time $t ; k_{1}$ and $k_{2}$ are equilibrium rate constant of pseudo-first $\left(\mathrm{min}^{-1}\right)$ and second order ( $\mathrm{g} \mathrm{mg}^{-1} \mathrm{~min}^{-1}$ ), respectively; and $t$ is the contact time, (h).

The values of pseudo-first-order rate constant $k_{1}$ and equilibrium adsorption capacity $q_{e}$ were calculated from the intercept and slope of the plot between $\log \left(q_{e}-q_{t}\right)$ versus $t$. The calculated $\log \left(q_{e}-q_{t}\right)$ and correlation coefficient $R^{2}$ values are presented in Table 2 .

The values of pseudo-second-order rate constant $k_{2}$ and equilibrium adsorption capacity $q_{e}$ were calculated from the intercept and slope of the plot between $t / q_{t}$ versus $t$ (Meenakshi and Viswanathan 2007). The calculated $q_{t}, k_{2}$ and correlation coefficient $R^{2}$ values are also presented in Table 3 .

From the data presented in Tables 2 and 3, it can be observed that the correlation coefficient values of pseudosecond order are more close to unity compared to those of

Table 2 Pseudo-first-order rate constants and the correlation coefficients along with the rate equations

\begin{tabular}{llll}
\hline Adsorbent & $k_{1}\left(\mathrm{~min}^{-1}\right)$ & Rate equation & $R^{2}$ \\
\hline MAA & & & \\
$16 \mathrm{mg}$ & 0.8410 & $\log \left(q_{e}-q_{t}\right)=-0.8410 t-0.6110$ & 0.9853 \\
$20 \mathrm{mg}$ & 0.5110 & $\log \left(q_{e}-q_{t}\right)=-0.5110 t-0.7210$ & 0.9767 \\
$24 \mathrm{mg}$ & 0.7210 & $\log \left(q_{e}-q_{t}\right)=-0.7210 t-0.7810$ & 0.9873 \\
Average & 0.6910 & & 0.9831 \\
MI & & & \\
$16 \mathrm{mg}$ & 0.9110 & $\log \left(q_{e}-q_{t}\right)=-0.9110 t-0.8120$ & 0.9960 \\
$20 \mathrm{mg}$ & 0.8120 & $\log \left(q_{e}-q_{t}\right)=-0.8120 t-0.8310$ & 0.9775 \\
$24 \mathrm{mg}$ & 0.7800 & $\log \left(q_{e}-q_{t}\right)=-0.7800 t-0.7910$ & 0.9880 \\
Average & 0.8343 & & 0.9872 \\
MA & & & \\
$16 \mathrm{mg}$ & 0.7210 & $\log \left(q_{e}-q_{t}\right)=-0.7210 t-0.9120$ & 0.9764 \\
$20 \mathrm{mg}$ & 0.6110 & $\log \left(q_{e}-q_{t}\right)=-0.6110 t-0.940$ & 0.9558 \\
$24 \mathrm{mg}$ & 0.5110 & $\log \left(q_{e}-q_{t}\right)=-0.5110 t-0.7800$ & 0.9960 \\
Average & 0.6143 & & 0.9761
\end{tabular}


Table 3 Pseudo-second-order rate constants and the correlation coefficients along with the rate equations

\begin{tabular}{llll}
\hline Adsorbent & $k_{2}\left(\mathrm{~g} \mathrm{mg}^{-1} \mathrm{~min}^{-1}\right)$ & Rate equation & $R^{2}$ \\
\hline MAA & & & \\
$16 \mathrm{mg}$ & 3.1995 & $t / q_{t}=3.1995 t+2.02002$ & 0.9983 \\
$20 \mathrm{mg}$ & 2.6176 & $t / q_{t}=2.6176 t+3.0788$ & 0.9957 \\
$24 \mathrm{mg}$ & 3.6477 & $t / q_{t}=3.6477 t+3.5587$ & 0.9923 \\
Average & 3.1549 & & 0.9954 \\
MI & & & \\
$16 \mathrm{mg}$ & 2.3486 & $t / q_{t}=2.3486 t+0.6502$ & 0.9950 \\
$20 \mathrm{mg}$ & 3.1894 & $t / q_{t}=3.1894 t+1.5306$ & 0.9955 \\
$24 \mathrm{mg}$ & 3.1252 & $t / q_{t}=3.1252 t+4.0667$ & 0.9950 \\
Average & 2.8877 & & 0.9952 \\
MA & & & \\
$16 \mathrm{mg}$ & 3.6508 & $t / q_{t}=3.6508 t+0.8464$ & 0.9964 \\
$20 \mathrm{mg}$ & 3.3300 & $t / q_{t}=3.330 t+1.8452$ & 0.9958 \\
$24 \mathrm{mg}$ & 2.1496 & $t / q_{t}=2.1496 t+4.0696$ & 0.9950 \\
Average & 3.0435 & & 0.9957 \\
\hline
\end{tabular}

pseudo-first order which indicates the data better fitted to pseudo-second-order reaction. Therefore, the adsorption process followed the pseudo-second-order reaction. This result is in agreement with that observed for clay adsorbents (Hassen 2007).

\section{Regeneration/reusability of the adsorbents}

It was observed that for all the adsorbents reusability can be done up to five times (Fig. 6). Best adsorbent for

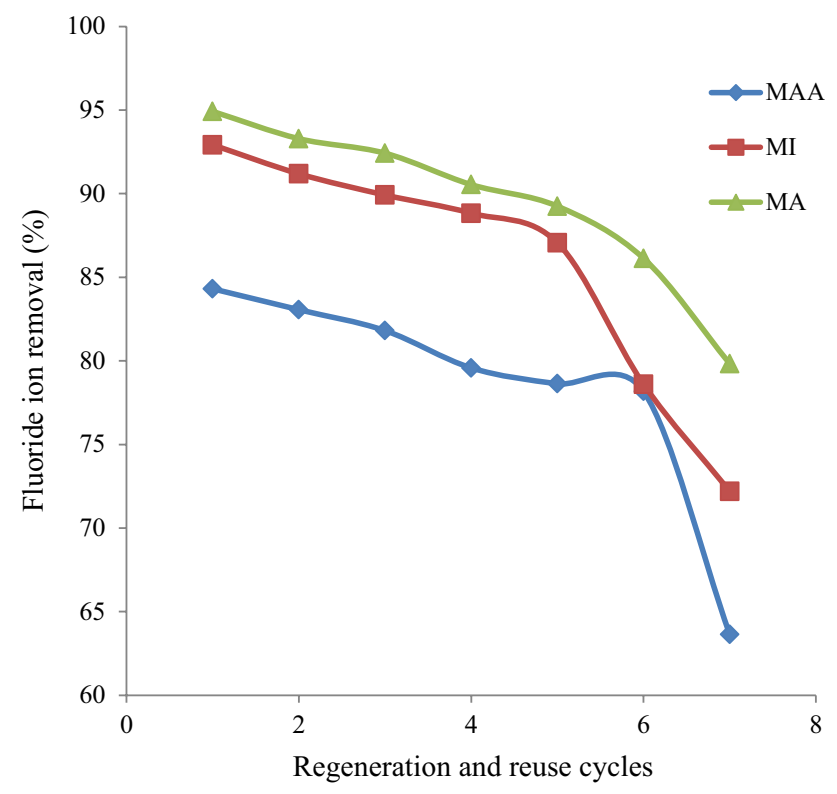

Fig. 6 Performance of the adsorbent for the removal of fluoride after regeneration and reuse regeneration was $\mathrm{MI}$ and $\mathrm{MA}$, because these adsorbents reduced fluoride concentration to the lowest acceptable level, even after reusing for 0-5th cycles, but after 6th and 7 th cycles it was not useful because it seems that fluoride removal decreased sharply due to lack of enough active sites for the fluoride binding and more electrostatic force of repulsion occurred. Therefore, coalesced adsorbents are better than un-coalesced ones for regeneration and reuse.

\section{Conclusion}

Characterization of adsorbent using XRF showed that elemental composition of mica after coalescing is different from that of before coalescing, indicating that impregnation improved surface characteristics for the adsorption of fluoride. XRD result showed good crystalline structure in mica. Optimization of different parameter like contact time, $\mathrm{pH}$, adsorbent dose, initial concentration, temperature and particle size for the adsorbents MAA, MI and MA revealed that all of these parameters were observed to be very important in the adsorption of fluoride, but adsorbent dose of $8 \mathrm{~g}$ was most important with adsorption per cent of $96.88 \%$. The adsorption process obeyed Freundlich model for MA indicating monolayer mechanism, whereas MAA and MI agreed with both Freundlich and Langmuir models indicating both monolayer homogeneous and heterogeneous surface conditions. The adsorption process followed the pseudo-second-order reaction kinetics. The adsorbent can be regenerated up to five times without losing its performance in removing fluoride. Coalesced mica is more effective in fluoride removal than un-coalesced activated mica. All the adsorbents studied in this research are very good alternatives for the treatment of water for fluoride decontamination and can be used by the community in both rural and urban areas.

Acknowledgements The authors thank Ngurdoto Defluoridation Research Centre (NDRC) at Arusha for providing chemicals, apparatus and equipment' for conducting experiments and also allowing them to work in their laboratories. Special thanks are also given to Geological Survey of Tanzania for XRF analysis and Twiga Cement Company in Dar es Salaam for XRD analysis.

Funding There is no any funding for this research work. This is selfsponsored research work done by Idd Ally Hussein under the supervision of the corresponding author Vegi Maheswara Rao of The University of Dodoma.

\section{Compliance with ethical statement}

Conflicts of interest The authors of this research declare that there is no any conflict of interest.

Research involving human participants and/or animals The authors of this research Idd Ally Hussein and Maheswara Rao Vegi declare

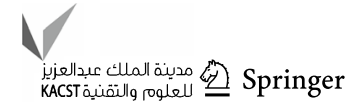


that there is no any participation of humans or animals in this work. This is completely experimental work conducted in the laboratory with different instruments.

Informed consent The authors of this research declare that there is no any informed consent in this study.

Open Access This article is licensed under a Creative Commons Attribution 4.0 International License, which permits use, sharing, adaptation, distribution and reproduction in any medium or format, as long as you give appropriate credit to the original author(s) and the source, provide a link to the Creative Commons licence, and indicate if changes were made. The images or other third party material in this article are included in the article's Creative Commons licence, unless indicated otherwise in a credit line to the material. If material is not included in the article's Creative Commons licence and your intended use is not permitted by statutory regulation or exceeds the permitted use, you will need to obtain permission directly from the copyright holder. To view a copy of this licence, visit http://creativecommons.org/licenses/by/4.0/.

\section{References}

Abdullah A, Shantanu K, Mohammad A, Hassan R (2013) Suitability of bentonite clay, an analytical approach. Int $\mathrm{J}$ Earth Sci 2(3):88-95. https://doi.org/10.11648/j.earth.20130203.13

Abe I, Iwasaki S, Tokimoto T, Kawasaki N, Nakamura T, Tanada S (2004) Adsorption of fluoride ions onto carbonaceous materials. J Colloid Interface Sci 275(1):35-39. https://doi.org/10.1016/j. jcis.2003.12.031

Agarwal M, Rai K, Shrivastav R, Dass S (2003) Defluoridation of water using amended clay. J Clean Prod 11:439-444. https://doi. org/10.1016/S0959-6526(02)00065-3

Alagumuthu G, Veeraputhiran V, Venkataraman S (2010) Fluoride sorption using cynodon dactylon-based activated carbon. Hem Ind 65(1):23-35. https://doi.org/10.2298/HEMIND100712052A

Baris K, Duygu O, Ali G, Volkan NB, Celal D, Mustafa S (2009) Removal of fluoride ions from aqueous solution by waste mud. J Hazard Mater 168:888-894. https://doi.org/10.1016/j.jhazm at.2009.02.109

Chakrapani C, Babu CS, Vani KNK, Rao KS (2010) Adsorption kinetics for the removal of fluoride from aqueous solution by activated carbon adsorbents derived from the peels of selected citrus fruits. J Chem 7(1):419-427. https://doi. org/10.1155/2010/582150

Chibi C, Haarhoff J (2000) A promising approach to fluoride removal in rural drinking water supplies. In: Presented at WISA 2000 biennial conference, Sun City, South Africa, pp 2-11. http:// citeseerx.ist.psu.edu/messages/downloadsexceeded.html. Accessed 26 Mar 2016

Chidambaram S, Manikindan S, Ramanathan AL (2013) A study on the defluoridation in water using natural soil. Appl Water Sci 4:741-751. https://doi.org/10.1007/s13201-013-0122-1

Coetzee PP, Coetzee LL, Puka R, Mubenga S (2003) Characterisation of selected south african clays for defluoridation of natural waters. Water SA 29(3):331-338. https://doi.org/10.4314/wsa. v29i3.4935

Deshmukh WS, Attar SJ, Waghmare MD (2009) Investigation on sorption of fluoride in water using rice husk as an adsorbent. Nat Environ Pollut Technol 8(2):217-223

Getachew T, Hussen A, Rao VM (2015) Defluoridation of water by activated carbon prepare from banana (Musa paradisiaca) peel and coffee (Coffea arabica) husk. Int J Environ Sci Technol 12:1857-1866. https://doi.org/10.1007/s13762-014-0545-8

Ghorai S, Pant KK (2004) Investigations on the column performance of fluoride adsorption by activated alumina in a fixed-bed. Chem Eng J 98(2):165-173. https://doi.org/10.1016/j.cej.2003.07.003

Hassen A (2007) Selection of clay adsorbents and determination of optimum condition for defluoridation for ground water. M.Sc. thesis, Addis Ababa University, Ethiopia, pp 26-27

Hussein IA, Rao VM (2017) Defluoridation of drinking water by using modified and unmodified bentonite from minjingu mining site in Tanzania. Int J Eng Sci Invent 9(6):46-56

Islam M, Patel RK (2007) Evaluation of removal efficiency of fluoride from aqueous solution using quick lime. J Hazard Mater 143:303-310. https://doi.org/10.1016/j.jhazmat.2006.09.030

Jamode AV, Sapkal VS, Jamode VS (2004) Defluoridation of water using inexpensive adsorbents. J Indian I Sci 84(5):163-171

Janardhana C, Nageswara Rao G, Sai Satish R, Sai Lakshman V (2006) Study on defluoridation of drinking water by impregnation of metal ions in activated charcoal. Indian J Chem Technol $13: 414-416$

Kaseva ME (2006) Optimization of regenerated bone char for fluoride removal in drinking water: a case study in Tanzania. J Water Health 4(1):139-147. https://doi.org/10.2166/wh.2006.0011

Kundu H, Basavaraj P, Singla A, Gupta R, Singh K, Jain S (2015) Effect of fluoride in drinking water on children's intelligence in high and low fluoride areas of Delhi. J Indian Assoc Public Health Dent 13(2):116. https://doi.org/10.4103/23195932.159043

Littleton J (1999) Paleopathology of skeletal fluorosis. Am J Phys Anthropol 109:465-483. https://doi.org/10.1002/(SICI)10968644(199908)109:4\%3c465:AID-AJPA4\%3e3.0.CO;2-T

Lugwisha EH, Lunyungu G (2016) Water defluoridation capacity of Tanzanian Kaolin-feldspar blend adsobents. Am J Appl Chem 4(3):77-83. https://doi.org/10.11648/j.ajac.20160403.12

Lv L, He J, Wei M, Evans DG, Duan X (2006) Factors influencing the removal of fluoride from aqueous solution by calcined $\mathrm{Mg}-$ $\mathrm{Al}-\mathrm{CO}_{3}$ layered double hydroxides. J Hazard Mater 133:119128. https://doi.org/10.1016/j.jhazmat.2005.10.012

Meenakshi S, Viswanathan N (2007) Identification of selective ionexchange resin for fluoride sorption. J Colloid Interface Sci 308:438-450. https://doi.org/10.1016/j.jcis.2006.12.032

Murugan M, Subramanian E (2006) Studies on defluoridation of water by tamarind seed, an unconventional biosorbent. J Water Health 4(4):453-461. https://doi.org/10.2166/wh.2006.0029

Olambo FL, Philip JYN, Mdoe JEG (2016) The potential of minjingu phosphate rock for water defluoridation. Int J Sci Technol Soc 4(1):1-6. https://doi.org/10.11648/j.ijsts.20160401.11

Othman OC, Philip JYN, Nkinda MS (2014) Use of activated red clay soil from kiteto district, Tanzania, as a remedial method for high fluoride levels in drinking water. Int J Sci Technol Soc 2(5):115-120. https://doi.org/10.11648/j.ijsts.20140205.14

Parmar S, Patel JB, Sudhakar P, Koshy VJ (2006) Removal of fluoride from water with powdered corn cobs. J Environ Sci Eng 48(2):135-138

Renuka P, Pushpanji K (2013) Review on defluoridation techniques of water. Int J Eng Sci 2(3):86-94

Said M, Machunda RL (2014) Defluoridation of water supplies using coconut shells activated carbon: batch studies. Int J Sci Res 3(7):2327-2331

Shan G, Jing C, Zhenggui W (2009) Study on the fluoride adsorption of various apatite materials in aqueous solution. J Fluor Chem 130:1035-1041. https://doi.org/10.1016/j.jfluchem.2009.09.004

Shorter J (2011) Fluoride in groundwater: investigating the cause, scale, effect and treatment of fluoride in drinking water in northern Tanzania. Doct. thesis, New Castle University, UK, pp $12-18$ 
Singano JJ, Mashauri DA, Dahi E, Mtalo FW (1995) Effect of pH on defluoridation of water by magnesite. In: 1st international workshop on fluorosis and defluoridation of water, Ngurdoto, Tanzania, pp 39-43. https://pdfs.semanticscholar.org/a2ff/85d9a c50b72ed560dee2ebfb94c3ae5338ef.pdf. Accessed 2 Apr 2016

Solangi IB, Shahabuddin Memon, Bhanger MI (2009) Removal of fluoride from aqueous environment by modified Amberlite resin. J Hazard Mater 171(1-3):815-819. https://doi.org/10.1016/j. jhazmat.2009.06.072

Tembhurkar AR, Dongre S (2006) Studies on fluoride removal using adsorption process. J Environ Sci Eng 48(3):151-156

Tokaryk E (2011) Biogeochemical defluoridation. Doct. Thesis, University of Toronto, Canada, pp 2-8
Vijaya Y, Krishnaiah A (2009) Sorptive response profile of chitosan coated silica in the defluoridation of aqueous solution. J Chem 6(3):713-724. https://doi.org/10.1155/2009/748153

Yadav AK, Kaushik CP, Haritash AK, Kansal A, Rani N (2006) Defluoridation of groundwater using brick powder as an adsorbent. J Hazard Mater B128:289-293. https://doi.org/10.1016/j. jhazmat.2005.08.006

Publisher's Note Springer Nature remains neutral with regard to jurisdictional claims in published maps and institutional affiliations. 